\title{
MEINHARD v. SALMON AND THE ECONOMICS OF HONOR
}

\author{
Nicholas L. Georgakopoulos*
}

I. Introduction ....................................................................137

II. The Dissent's Point: Can't Partners

Reap the Fruit of their Luck? ....................................141

III. Benefits of Broad Fiduciary Obligations.......................146

A. Broad Duties Enable Financing................................146

B. Broad Duties Mitigate Risk-Aversion......................148

C. Efficient Market Financing Decisions ......................149

D. Efficient Managerial Incentives ...............................150

IV. The Limited Choice of Fiduciary Levels

Necessitates Broad Obligations...................................152

V. Conclusion: Honor in Defensive Tactics ......................153

VI. Appendix: Broad Fiduciary Duties

Enable Financing and Mitigate

Risk-Aversion.

\section{INTRODUCTION}

The utmost specimen of a classic corporate case is Meinhard v. Salmon. ${ }^{1}$ Cardozo's powerful rhetoric and sensitive morality instills confidence in every student who doubts the propriety of this breed of capitalism. Generations of corporate lawyers have been schooled in its memorable language finding broad fiduciary obligations on managers of other peoples' money:

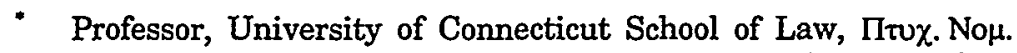
(Law Dip.) '87, Athens U. Law School; LL.M. '88, S.J.D. (Econ. Anal. of L.) '92, Harvard Law School. I wish to thank Craig Albert, Phillip Blumberg, C. Robert Morris, Ellen Ash Peters, and Steve Utz as well as the 1998 Canadian Law and Economics Association conference participants for their invaluable comments.

249 N.Y. 458 (1928). 
Many forms of conduct permissible in a workaday world for those acting at arm's length, are forbidden to those bound by fiduciary ties. A trustee is held to something stricter than the morals of the marketplace. Not honesty alone, but the punctilio of an honor the most sensitive, is then the standard of behavior. As to this there has developed a tradition that is unbending and inveterate .... Only thus has the level of conduct for fiduciaries been kept at a level higher than that trodden by the crowd. ${ }^{2}$

A fundamental paradox, however, lies in the attraction of Meinhard to corporate law teachers. The case's appeal appears to lie in its rhetoric and morality, while most corporate law courses seek to make economic sense out of business law. ${ }^{3}$ No less an economic analysis scholar than Richard Posner, in studying Cardozo's opinions closely in his book on Cardozo's reputation, categorizes Meinhard as a moralistic case, which exemplifies Cardozo's rhetorical powers. Posner, however, fails to realize that Cardozo's uncanny economic intuition was equally at work here as in any other of his famous opinions. ${ }^{4}$

2 Id. at 464.

3 The importance of economic analysis in the teaching of corporate law is evident in the results of a survey on the methods used in the basic corporate law course, where $64 \%$ of the professors stated they use economic analysis often or recurringly (13 often and 30 recurringly, for 43 out of 67 responses; 17 more use it a little). See Robert B. Thompson, The Basic Business Associations Course: An Empirical Study of Methods and Content, $48 \mathrm{~J}$. LEGAL EDUC. 438, 445 (1998), available at $<$ http://s.wustl.edu/ thompson/themes.htm> (visited Feb. 21, 1999). The paradoxical use in this setting of Meinhard v. Salmon is evident because six out of the seven current Corporate Law casebooks include Meinhard (the authors of the books that include it are O'Kelley \& Thompson; Seligman; Hamilton; Choper, Coffee \& Gilson; Cary \& Eisenberg; only that of Solomon, Schwartz, Bauman \& Weiss does not).

1 Posner calls Meinhard "the most famous of Cardozo's moralistic opinions" and argues that "it is possible to object that [the above excerpt from Meinhard is] just words, and florid ones at that. But they are memorable words, and they set a tone." RichARD A. POSNER, CARDOZO A STUDY IN REPUTATION 104-105 (1989) (discussing Meinhard in a single 
This short article seeks to overturn the myth that the decision in Meinhard was based on morality alone. If Meinhard is not Cardozo's best opinion from an economic perspective, it is certainly one of the best examples of his astonishing gift to provide the economically advantageous rules in an irresistible dress of moral appeal and graceful prose. The economic principle of broad fiduciary obligations that lies behind Meinhard forms a cornerstone of managerial capitalism that has allowed passive investment in professionally managed corporations. The Meinhard principle also enabled the world-wide spread of managerial capitalism. Moreover, to the consternation of continental European legal systems that are currently trying to emulate the creative drive of common-law-developed venture capital, Cardozo has already proffered the answer: under narrow fiduciary duties, projects with primarily remote opportunities will not be financed. Indeed, the average venture capital investment in the U.S. is a minority equity stake in a young enterprise. ${ }^{5}$ By contrast, abroad minority equity in-

paragraph in a 150 page book while Palsgraf v. Long Island R.R. Co., 248 N.Y. 339 (1928), receives a 15-page treatment and the obscure Hynes $v$. N. Y. Central R.R. Co., 231 N.Y. 229 (1921), occupies 9 pages).

- See, e.g., Curtis J. Milhaupt, The Market for Innovation in the U.S. and Japan: Venture Capital and the Comparative Corporate Governance Debate, 91 Nw. U. L. REv. 865, 875 (1998) (detailing how total venture capital investment in U.S. firms averages a $34 \%$ equity stake, $19 \%$ of which is owned by the lead venture capitalist). It is interesting to note that since the average stake of the venture capitalist is a minority stake, it creates doubts about the convoluted theory that venture capitalists and entrepreneurs have an implicit contract about control which the venture capitalists return to the entrepreneur when they sell their stakes at an initial public offering (IPO). See generally Bernard S. Black \& Ronald Gilson, Venture Capital and the Structure of Capital Markets: Banks versus Stock Markets, 47 J. FIN. ECON. 243 (1998). Note that if a minority investment were appealing in a narrowfiduciary-obligation legal system, nothing would preclude venture capitalists of France, Germany, or Japan from conducting an IPO in the US. 
vestments are avoided, and the venture capitalists lend to much more established and safer enterprises. ${ }^{6}$

Part II of this article will briefly discuss Meinhard and the potential merits of Justice Andrews' bitter dissent. Part III will recast the facts of the case in the typical example of a passive investor's decision whether to invest in a project. This will show how Cardozo's outcome helps financing and lowers the cost of capital. Part IV shows that the desirability of broad fiduciary obligations is unassailable even by the most deregulatory-spirited application of the Coase test: not only are the broad fiduciary duties of Meinhard the appropriate default rule, but broad fiduciary obligations are necessary even as a contracting tool. This conclusion points out that, however justified the hiatus of discretionary takeover defenses may have been, it may be time to return to higher standards of fiduciary obligations in the context of defensive tactics. The appendix provides a formal analysis which demonstrates that projects which will provide a large part of their expected return in probabilistic opportunities (as opposed to safe cash flows) will only be undertaken by riskaverse managers if fiduciary obligations are expansive.

6 Milhaupt, supra note 5, at 877-78 (arguing that $30 \%$ of all venture capital disbursements in the U.S. are to the earliest stages of firms: seed, start-up, and early stage financings, while only $16 \%$ of Japanese venture capital goes to firms in similar stages and even that tends to go to much safer and less innovative firms in safer industries). Compare Hermann H. Kallfass, The American Corporation and the Institutional Investor: Are There Lessons from Abroad? The German Experience, 1988 CoLUM. Bus. L. REv. 775, 787-89 (1988) (noting the difficulty that young firms face in getting venture capital financing in Germany). 


\section{The Dissent's Point: Can't Partners Reap the FRUIT OF THEIR LUCK?}

The facts of the case are not complicated. The wool merchant Morton Meinhard helped a budding real estate developer, Walter Salmon, finance a project in exchange for a share of the profits. Salmon had identified an appealing investment in the Hotel Bristol, a building in the northwest corner of Fifth Avenue and Forty-Second Street in Manhat$\tan$. The Bristol, with its bay windows and ornate arched friezes, had character but would soon be outdated. Its seven-story structure had a $741 \frac{1}{2}$ foot face on Fifth Avenue and a 125 foot face on Forty-Second Street, for a footprint of

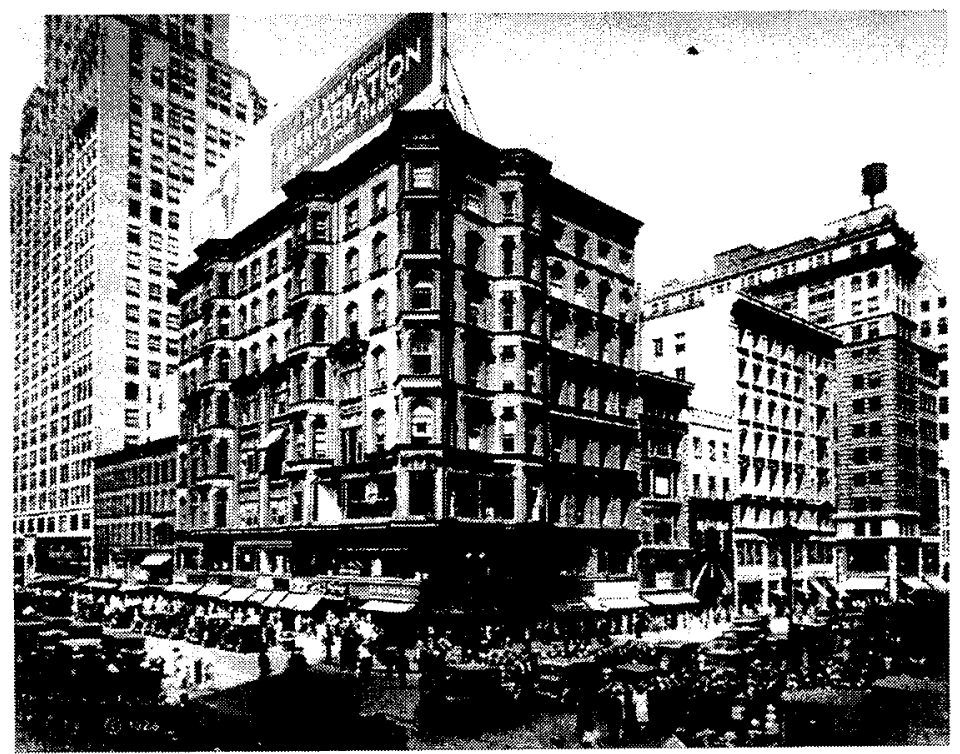

Picture 1: The Bristol in 1928. Note the distance and height of the next skyscraper on Forty-Second Street. Corbis/Bettman`

9,312.5 square feet. ${ }^{7}$ The picture, taken from across the intersection, shows the Bristol in the foreground in 1928. The two developers, operating through the only visible partner,

See Meinhard v. Salmon, 223 A.D. 663, 667-68 (N.Y. App. Div. 1st Dept. 1928). 
Salmon, obtained a 20-year lease of the Bristol starting in 1902. Given its golden location-two blocks from Grand Central Station and across from the new Public Library that replaced in the early twenties the reservoir which was there at the beginning of the lease-it is not surprising that after costly renovations and a few years of losses, the operation turned magnificently profitable. Their cooperation was otherwise uneventful until the lease was about to expire. Elbridge Gerry, the owner of the land, unaware of Meinhard's existence, approached Salmon with a proposal to expand the lease to encompass several adjoining lots which were by that time also owned by him. The new project was to have a 100.5 foot face on Fifth Avenue and 208 foot face on Forty-Second Street. ${ }^{8}$ Its footprint, at 20,904 square feet, was more than double that of the old building. Salmon, no longer in need of Meinhard's financial backing, accepted the offer in his own name and undertook a project of an entirely different scope than renovating and managing a single building. The new project ended up much larger than initially planned. While it was contracted to be at least 25 stories, comparable in size with the neighboring high-rise on Forty-Second Street, the resulting structure was an imposing 59-story art-deco skyscraper resembling a cubist puzzle. Its picture shows how its vertical lines and its soaring presence provide a dramatic backdrop for the classic and horizontally laid out New York Public Library. The new building was obviously a feather in the cap of its architects, the premier architectural firm of Shreve, Lamb \& Harmon, designers of the Empire State Building, the General Motors Building, and Hunter College, among others. ${ }^{9}$ The building has always been known as "500 Fifth Avenue." It is still the second tallest building in the neighborhood after the Empire State Building.

See id.

See Elliot WILLENSKY \& NORAL WhITE, AIA GUIDE TO NEW YORK City 240 (3d ed. 1988); 4 MACMILLAN ENCYClOpedia of ARchitects 54 (Adolf K. Placzek ed. 1982). 


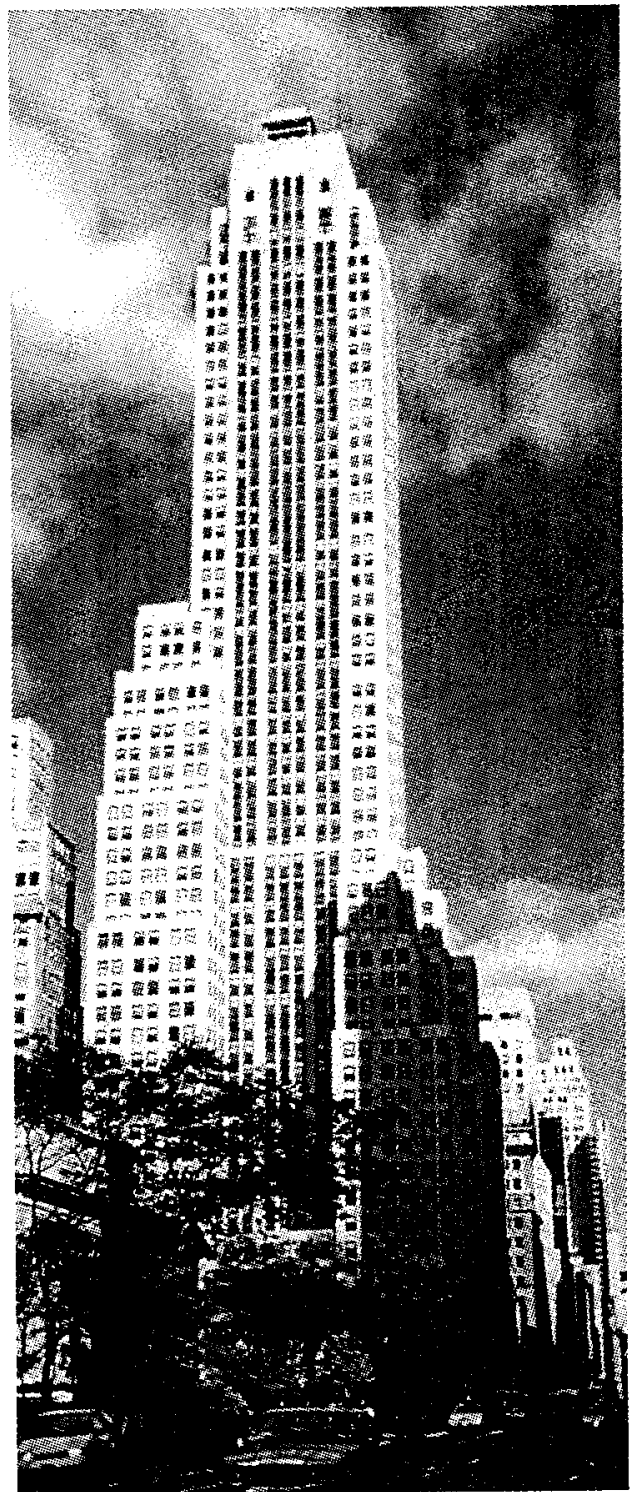

Picture 2: 500 Fifth Avenue in 1998. Compare the location and height of the neighboring skyscraper. 
The dissent's point is well made: the partners' original project was of an entirely different scope than Gerry's new proposal. Had the lease simply been renewed, Meinhard certainly should have been allowed to participate. Because of its uniqueness from the original project, the new proposal was one that Salmon could easily have acquired on his own given his reputation as a savvy real estate developer.

The strength of the dissent is not so much that this offer was clearly a fruit of Salmon's personal efforts, skills, or reputation, but that even partners are entitled to some personal sphere of independent activity. That Salmon joined a partnership clearly should not preclude him from ever conducting business in his personal capacity outside it. The dissenting Justice Andrews strongly believed that the offer to Salmon was an offer to the individual, not the partner.

The issue, however, is not the application of an existing standard but the creation by Cardozo of a new one. Thus, the issue is not where the divide lies between the personal versus partnership opportunity in this particular case (after all, Cardozo was not above distorting facts to reach his holdings ${ }^{10}$ and the economic ramifications of this decision actually favored the ostensibly losing party, Salmon ${ }^{11}$ ) but

10 The opinion in Palsgraf v. Long Island R.R. Co. can easily be interpreted as the result of a judge on a mission to adopt the rule that only foreseeable plaintiffs can have negligence claims. In the opinion the facts are distorted and omitted to stress the remote nature of the plaintiffs injury (which was suffered at the "other end" of the station platform while in truth "over 10 feet away" and constituted of a stammer) from the railroad's negligence (in helping two "Italian"-looking types onto a leaving train with a large packet that the opinion makes "small"; neither the immensity of the explosion nor the lack of any injury to the Italians is mentioned in the opinion). Palsgraf v. Long Island R.R. Co, 248 N.Y. 339 (1928). See also POSNER, supra note 4, at 33-48, (discussing Palsgraf).

11 Salmon retained majority control of the expanded project, which due to the depression was not successful, and anecdotally, only the cash infusion of Meinhard saved Salmon from ruin during the lean years. Salmon felt so grateful that he sent Cardozo a bouquet of flowers on each anniversary of the opinion. Moreover, when Meinhard died, his share was sold to the Salmon family at the depressed prices of the day. See Correspondence with C. Robert Morris, Professor of Law at Minnesota 
rather Cardozo's message that fiduciary obligations must be interpreted broadly. The Meinhard opinion can be credited for this legal system's escape from the narrow construction of fiduciary obligations that allows countries like the Federal Republic of Germany to condone such broad managerial powers that allowed Daimler-Benz management, for example, to hide $\$ 2.8$ billion $-17 \%$ of its postannouncement capitalization, $26 \%$ of its book value - from their shareholders until forced to reveal it by U.S. standards. ${ }^{12}$

Thus, we start discerning the true issue of Meinhard $v$. Salmon. Managers, just like Salmon, inevitably receive some advantages due to the visibility, the networking, and the general activity of their positions. Some of those advantages may clearly flow from the manager's persona, such as individual skills, reputation, or charisma. Others may arise from the organization and could be clearly traced to the manager's employer or principal. Perhaps one could inquire into the state of mind of the offeror, such as Gerry, when this advantage involves an outsider's offer. The unusual facts of Meinhard made such an inquiry useless because Salmon was ostensibly the sole owner and operator of the Bristol. Gerry did not know any other entity to be involved in the lease of the Bristol. Often, however, the advantage the manager receives will involve not an offer but the random appearance of an opportunity. Salmon's daily route to the Bristol may have created the opportunity by

Law School, Feb. 2, 1998 (on file with author) (relating facts extracted and generously shared by Professor Morris from Walter Salmon Jr. in 1983-84). Furthermore, Professor Craig Albert, who examined the record at the New York City Bar while on a breather from correcting exams, claims that Meinhard was trying to force Salmon into giving him a better deal than $50 \%$ participation by dragging his heels (he transferred his interest to his wife, and when Salmon accepted in principle a $50 \%$ participation of Meinhard but not of his wife, Meinhard brought suit). See E-mail from Craig Albert, Associate Professor, Seton Hall Law School, Feb. 9, 1999 (on file with author).

12 See The Global 1000, Bus. WK., July 12, 1993, at 52; see also Floyd Norris, Market Place: Daimler-Benz paves the way for other German companies, N.Y. TIMES, Mar. 31, 1993, at D8. 
allowing him to observe the activity in a building a few blocks away. Alternatively, Salmon, as the manager, may have found an unclaimed valuable item in the premises of the Bristol. Random accruals must be separated between those that go to the agent-manager and those that go to the employer-principal. Therefore, the law must draw a line to separate the position between what opportunities should accrue to the individual and what should accrue to the partnership, and the dispute between Cardozo and Andrews ultimately involves where that line should be drawn. The facts of Meinhard v. Salmon can be stylized to form the prototype of the choices involved, not only for the parties but also for the legal system.

\section{BENEFITS OF BROAD FIDUCIARY OBLIGATIONS}

Broad fiduciary obligations facilitate the financing of ventures, mitigate the effects of managers' risk-aversion, align the financing decisions of investors with the true economic desirability of projects, and align the incentives of managers with the benefit to the economy and the desires of investors. The facts of Meinhard are a beautiful illustration of these effects.

\section{A. Broad Duties Enable Financing}

To observe the influence of fiduciary obligations on the financing of the Bristol, we must begin with hypothetical alternatives in which Meinhard could have invested his capital. Suppose that for a risk comparable to a real estate project like that of the Bristol, Meinhard could place funds in the wool trade and receive an expected annual real return of 5\%. Salmon's proposal to develop the Bristol would only be attractive if it offered at least the same $5 \%$. Thus, the question is how Meinhard's expected return, before investing in 1902, would have been influenced by the scope of fiduciary obligations.

Let us suppose that Meinhard and Salmon would split the renovation costs of $\$ 200,000$ and the ensuing profits 
equally (in truth most of Salmon's contribution may have been in labor, but that does make it immune from valuation). Therefore, Meinhard expects his $\$ 100,000$ contribution to produce $\$ 5,000$ of net real profits annually for the duration of the lease. Since $\$ 5,000$ is $5 \%$ of the $\$ 100,000$ investment, for Meinhard to realize a 5\% return he must expect to recover $\$ 100,000$ at the end of the lease. Suppose that three possible outcomes are expected with the following probabilities at the end of the 20 years. First, Gerry may sever their ties with $25 \%$ probability, leaving the developers empty-handed. Second, Gerry may renew the lease with 50\% probability, or third, he may propose the expansion to the entire block with $25 \%$ probability. Extension continues the $\$ 5,000$ annual profit of Meinhard for the foreseeable future. For a cost of capital of $5 \%$, this perpetuity is worth $\$ 100,000$, or $\$ 50,000$ in this case where it is a $50 \%$ proposition. This is all that Andrews would give to Meinhard, and it would fall short of producing the $5 \%$ he requires.

Cardozo, however, also allows Meinhard to participate in the expanded lease. We should suppose that the larger venture was expected to provide $\$ 10,000$ annual net profits to each, which means $\$ 200,000$ for someone, like Meinhard, who has a 5\% cost of capital. The $25 \%$ chance of earning $\$ 200,000$ is worth $\$ 50,000$. Thus, Cardozo's wide fiduciary obligations do restore the $\$ 100,000$ investment to Meinhard, render the project attractive, and enable its financing.

The lesson of the Meinhard example is that broad fiduciary obligations lead investors to expect a greater fraction of a project's remote potential. This expectation of greater remote gains allows the financing of projects with meager immediate gains. In the extreme cases where most of a project's value is in remote opportunities, even if the investor were to receive $100 \%$ of the project, its immediate returns would not provide the necessary return. By contrast, if the remote opportunities are considered part of the project, the investor would need less participation to receive the required return. This impossibility of financing under narrow fiduciary duties is formally developed in the appendix. 
The difficulty of financing projects under narrow duties exists even if the parties may override it, i.e., if it is only a default rule. Some cash-flow-poor projects would be unable to change the default rule. One can readily see an example of this effect by considering that overriding the default in the stylized Meinhard example, above, would cost $\$ 1,000$ in legal fees. That would require Meinhard to increase his contribution by $\$ 1,000$ and would leave the project unable to be financed. Meinhard would require slightly more than 50\% participation to recoup the $\$ 1,000$, but such a division may be insufficient for Salmon, either because it increases his risk too much (explained below) or because his reduced cash flow cannot sustain his livelihood until the end of the lease.

Thus, Cardozo's broad fiduciary obligations are a crucial step toward the formation of an economic system that relies on financing by passive investors and on the decentralized decision-making that financial markets make possible. But broad fiduciary obligations do much more than enable the financing of projects with remote value.

\section{B. Broad Duties Mitigate Risk-Aversion}

Narrow fiduciary obligations aggravate risk-aversion problems. Take our paradigmatic Salmon and the resulting risks of the project to him if it could have been financed under narrow fiduciary duties. Since the partnership will receive an expected value of only $\$ 100,000$ in 1922 according to Andrews, for Meinhard to receive his 5\% return on his investment, his participation must be $61.61 \%$ of the project. ${ }^{13}$ Salmon's share of the Bristol's income is reduced, but he is compensated by the fact that he will receive the entire gain from an expansion of the lease in

13 The calculation goes as follows. Meinhard must still invest $\$ 100,000$, and the only issue is what fraction of the enterprise that will be considered to comprise. The fraction must be set so that when applied to annual earnings and the final value that Andews' interpretation gives to the firm, it allows Meinhard to have realized a 5\% return. That is $61.61 \%$, giving Meinhard $\$ 6,161$ annually and making his share of the terminal value $\$ 61,610$. 
1922. Notice, however, that this has made the project riskier for Salmon, by increasing the fraction of his total value that is contingent on the expansion materializing. If Salmon is risk-averse, as managers who must stake their future on a single firm (or even a few) are, then narrowing the fiduciary obligations is undesirable. By contrast, the typical investor is diversified and nearly risk-neutral. Broad fiduciary obligations move risk from the risk-averse to the risk-neutral, making the entrepreneurs better off without hurting investors. Therefore, even if a project could be financed regardless of fiduciary level, it is more likely to be undertaken where fiduciary obligations are broader.

That broad fiduciary obligations mitigate managerial risk-aversion points out why an economy cannot afford to rely on self-financing as a substitute for broad fiduciary obligations. Self-financing aggravates the risk of the project for the entrepreneur. It is practically impossible that the financial investment in the entrepreneur's own venture is no greater than would be dictated by a perfectly diversified investment strategy. Thus, the self-financing entrepreneur takes not only a risk with human capital (as does the one who relies on investor financing) but also a risk with financial capital (while diversified investors do not). Therefore, we should expect self-financing entrepreneurs to require more profitability before undertaking a project than would an investor-financed entrepreneur.

\section{Efficient Market Financing Decisions}

Broad fiduciary obligations also align financing decisions with the social desirability of projects. The remote opportunities a project may create are part of its social desirability, part of its potential contribution to the national product. Narrow fiduciary obligations distort the decision of financial markets since a project with smaller but immediate opportunities will appear more lucrative than a more valuable project that derives most of its value from the remote opportunities it will generate. Broad 
fiduciary obligations cure this discrepancy because project investors will include more of the remote value that a venture will generate in their project assessments.

In the Meinhard example this becomes obvious if one compares the social desirability of Meinhard's investment alternatives: Meinhard could either renovate the Bristol and prepare further development of the area or he could put the same money in his wool trade or another more mature project. Hypothetically, a benevolent central planner would choose the project that presented the greatest increase in welfare-the one that would be expected to most increase the national product. In calculating the national product, however, the potential to elevate a developing area and prepare the market for larger projects would be included, since social welfare includes the creation of all opportunities. Hence the central planner would take into account the opportunities each alternative may generate. If Meinhard expects the project to be regulated by Andrews' narrow fiduciary duties, he will not include them in his calculation. For example, if Salmon proposed two projects, a mature project with richer cash flows and a more "farsighted" project, the Bristol, that had the capacity to lead to further development, clearly the Bristol, the more desirable project, would not stand out. Cardozo's broad fiduciary obligations bring the investor's interests closer to those of society and lead to better investing decisions from the social welfare perspective.

\section{Efficient Managerial Incentives}

An extension of this idea of the socially desirable decision-making of capital markets is that broad fiduciary duties create socially desirable managerial incentives. If managers are compensated not only by sharing investors' returns but also by appropriating opportunities a project generates, there will be a distortion in the form of managerial compensation. Projects that generate most of their value in remote opportunities will offer little compensation in the form of shareholdings to managers 
who would be reaping most of the remote opportunities. Projects where most of the payoffs are immediate gains, will need to compensate managers directly for the opportunities they forego. Thus, narrow fiduciary obligations create a bias that disfavors projects with remote gains. This bias may be unimportant if the performance of the projects does not depend on managerial effort. However, when project performance does depend on managerial effort, managers will not be sufficiently motivated by the potential gains from opportunity-rich. projects, because managers receive less of their remuneration in the form of participating in the same payoffs that investors receive and more of their remuneration in the form of reaping the project's opportunities. Thus, the incentives that managers receive under narrow duties are inconsistent with the goals of both investors and society. Under narrow duties, Meinhard, for example, would rather see Salmon reduce costs than effectuate any increase in the expected value of the remote opportunity (the expansion). Salmon, on the other hand, with a reduced share of the cash (under $40 \%$ ), would rather increase the expected opportunity by $\$ 40$ than reduce costs by $\$ 100$. The economy, of course, would be indifferent between wealth created in remote versus immediate opportunities. Regardless of whether Meinhard succeeds in motivating Salmon to reduce costs or Salmon gets away with putting his efforts in the remote value of the project, society suffers.

Broad obligations, however, realign incentives. Salmon is unbiased because he receives the same share of immediate and remote value, as does Meinhard, and both types of value contribute equally to the national product. Thus, an economy with broad fiduciary obligations will have at least four significant advantages over a narrow fiduciary obligation economy: (1) projects will be financed that could not otherwise have been; (2) projects will be undertaken that would not be otherwise, even if they could have been financed; (3) the financial markets' decisions will be more beneficial to the economy; and (4) managerial 
incentives will be aligned with investor desires and, more importantly, with social welfare. The moral and the rhetorical appeal, for which Cardozo's Meinhard is famous, are trivial compared to its economic effect.

\section{THE LIMITED CHOICE OF FIDUCIARY LEVELS NECESSITATES BROAD OBLIGATIONS}

Much of the deregulatory zeal of the economic analysis of law is the result of excessive confidence in Coase's argument that parties can negotiate around suboptimal rules. This renders even optimal rules superfluous if they could be reached by the parties. ${ }^{14}$ To justify legal rules in the face of the Coasean objection, one must show that parties would be unable to reach the optimal arrangement unassisted by the legal system.

The Coasean objection is weak when applied to the issue of whether fiduciary obligations should be interpreted broadly or narrowly. Fiduciary obligations should have a wide scope even if the parties could tailor their scope contractually. Broad fiduciary obligations are obviously necessary to allow parties to meaningfully customize them to their relationship. The legal system provides for only two levels of trust and their differentiation is necessary for them to be useful tools for parties setting up relationships.

In essence, legal systems provide only two levels of loyalty between contracting parties, arm's-length and fiduciary relationships. The difference in the degree of trust that the two levels of loyalty entitle the parties is dramatic. Fiduciary relations impose a pure duty of loyalty, according to which the fiduciary must place the interests of his employer before his own. Arm's-length relations, by contrast, allow exploitation within the parameters of good faith.

Indirect methods may be developed, however costly and complex, which allow parties to customize their fiduciary

14 See generally Ronald H. Coase, The Problem of Social Cost, 3 J.L. \& ECON. 1 (1960). See also generally A. Mitchell Polinsky, AN INTRODUCTION TO LAW AND ECONOMICS (2d ed. 1989) (offering a very readable elaboration of the Coase "theorem"). 
burdens. For example, if the parties want to reduce the participation of the financier in future opportunities, they can divide the financing into debt and equity. Thus, instead of the stylized Meinhard receiving half of all profits and opportunities, he would expect a smaller fraction in exchange for seniority in the claims against income. Such an arrangement does not necessarily involve debt and the bankruptcy risk it may entail during temporary cash shortages. The same can be achieved by issuing preferred stock. Thus, contracting parties can determine the rates with which they participate in unusual opportunities.

However, since that mix contains only two elements, contracting parties cannot create levels of fiduciary obligations outside the two choices: arm's-length or fiduciary relations. That is, parties cannot agree to give the investor fewer opportunities than a pure arm's-length relationship or more opportunities than a pure fiduciary relationship. The farther apart the legal system keeps the definitions of the two, the more latitude parties have to fine-tune their relationships. In order to expand contracting choices, the two levels of loyalty available must be kept as far apart as possible. The rhetoric of Meinhard, if nothing else, preserves the expansive interpretation that fiduciary duties should receive. Without the expansive fiduciary obligations Cardozo provides, the parties would not be able to require strict loyalty to govern their obligations even in those cases where strict loyalty would be desirable. Thus, there are more compelling justifications for having broad fiduciary obligations than that they serve as a convenient default term.

\section{ConClusion: HoNOR IN DEFENSIVE TACTICS}

In principle, the way economic forces and incentives operate remains constant, although the technologies, wages, prices, and interest rates change constantly. Thus, no reason should exist why the economy of the twenty-first century should not follow the wise course that Cardozo charted in Meinhard for that of the twentieth. Indeed, the new Re- 
vised Uniform Partnership Act reflects Cardozo's approach by maintaining a high fiduciary standard. ${ }^{15}$ Nevertheless, a fundamental deviation has arisen in current law. The law of defensive tactics has constantly been moving farther from the concept that directors must place shareholder interests foremost.

The field of takeover defense law has witnessed a movement in support of incumbent management. The courts' initial stance that directors defending against hostile threats have a conflict of interests in such situations has been reduced to virtually empty rhetoric. Nearly any corporate policy will suffice for the courts to allow incumbent management to destroy billions of dollars in shareholder value. ${ }^{16}$ Furthermore, state legislatures operating under the pressure of business and labor, have tried to provide ammunition to incumbent management in fending off hostile buyers. ${ }^{17}$ The result is that the rightful recipients of

15 The new Revised Uniform Partnership Act ("RUPA") maintains a high standard of fiduciary obligations. See, e.g., REv. UNIF. PARTNERSHIP ACr § 103(b)(5) (1996) ("The partnership agreement may not . . . (5) eliminate the obligation of good faith and fair dealing ...."). See Donald J. Weidner \& John W. Larson, The Revised Uniform Partnership Act: The Reporters' Overview, 49 Bus. LAW. 1, 16-24 (1993). But see Larry E. Ribstein, The Revised Uniform Partnership Act: Not Ready for Prime time, 49 Bus. LAW. 45, 52 (1993) (attacking this feature of the new RUPA).

${ }_{16}$ The paradigmatic case is Paramount Communications, Inc. $v$. Time, Inc., where Time's "strategic alliance" with Warner was enough for the courts to allow management to prevent shareholders from choosing between the $\$ 200$ Paramount offer and management's proposed alliance, worth about $\$ 120$ per share but in hindsight much less, thus prevented the shareholders from nearly doubling their money. 571 A.2d 1140 (Del. 1990).

17 The two principal legislative means of protecting the control of the corporation by incumbent boards are the constituency statutes, which entitle the board to take into account non-shareholder stakeholders of the corporation in the exercise of its fiduciary duties, and the transfer-delaying (but in effect, control-protecting) takeover statutes. See, e.g., CTS Corp. v. Dynamics Corp. of America, 481 U.S. 69 (1987) (involving such a takeover statute); see also Roberta Romano, Competition for Corporate Charters and the Lesson of Takeover Statutes, 61 FORDHAM L. REv. 843 (1993) (discussing how such statutes have been 
management's fiduciary duties, the shareholders, find their interests subordinated to a host of other stakeholders in the firm, including management.

It is very important to note, however, that a frenetic pace of takeover activity may not be in society's best interests. While in principle takeovers should accelerate the transition to new technology, takeover fever entails a temporary danger. As takeovers close old-fashioned plants and productive processes, they displace employees that need training and sustenance until they are employable in the new economy. Too fast a takeover market may displace too great a fraction of the workforce, leading to poverty, despair, and pauperism. A desirable transition may occur too fast for comfort. Takeover defenses did help slow the retooling of the American economy and may have prevented a dramatic social crisis.

At some point in time, however, the legal system should take its foot off the brake. When the transition of the economy is nearly complete, there is no reason to sacrifice shareholder interests any longer. In fact, there could hardly be a better time to pursue further optimization of industrial organization than the current one of low unemployment and steady growth. Courts and legislatures must allow the market place, once again, to pursue the maximization of shareholder value.

\section{APPENDIX: BROAD FIDUCIARY DUTIES ENABLE FINANCING AND MITIGATE RISK-AVERSION}

A manager-entrepreneur conceives a project which needs outside financing and managerial effort corresponding to a reservation salary $x$. The venture will generate two types of payoffs, foreseeable cash flow and probabilistic opportunity. The venture will produce cash flows $f$ and, with probability $p$, will give rise to an opportunity with value $o$ which will lie at a distance $d$ from the objective of the venture. If $d=0$ the

the result of special interest group pressure and are, generally, undesirable). 
opportunity will have arisen from the venture alone, while if $d=1$ the opportunity will have arisen purely from efforts and attributes of the manager that are unrelated to the venture. The distance $d$ is uniformly distributed between 0 and 1 with cumulative distribution $G(x)=x$ and probability density $g(x)=1$.

The legal system determines the definition of opportunities that are considered "corporate" and belong to the enterprise, by determining the level of fiduciary obligations. Thus, the legal system can be considered as setting the fiduciary obligation parameter $b$. If, then, the distance $d$ of an opportunity from the venture is not greater than the obligation parameter $b(d \leq b)$, the courts conclude that the opportunity belongs to the enterprise. The uniform distribution of $d$ implies that an opportunity is corporate with probability $b$. If, by contrast, an opportunity materializes with a distance from the project that is greater than the obligation parameter $(d>b)$, then the courts would award the opportunity to the manager. Thus, the legal system may choose an expansive definition of corporate opportunities by setting a large $b$ (closer to 1 ), or a narrow definition by choosing a small $b$ (closer to 0 ). It would be false to consider this a zero-sum game and conclude that expansive definitions of fiduciary obligations are as onerous for managers as they are advantageous for investors. Such a conclusion would only be true if the parties' agreement did not take the level of fiduciary obligations into account.

The investor requires a competitive return to invest in the venture, which implies a total expected payment of $r$. The investor will be given a share $s$ in the venture. Therefore, if the opportunity does materialize (with probability $p$ ) and is corporate (with probability $b$ ) the investor receives a share $s$ of the cash $f$ and of the opportunity $o$. Otherwise, with probability $(1-p b)$, the investor receives only his share $s$ of the cash $f$, i.e., $s f$. The investor's expected payoffs must at least equal $r$, but competitive capital markets will restrict the investor to no more than $r$, determining his participation $s$ : 


$$
\begin{aligned}
& p b s(f+o)+(1-p b) s f=r \quad \Leftrightarrow \\
& s=\frac{r}{f+p b o}
\end{aligned}
$$

Even if the entrepreneur were risk-neutral, not all attractive ventures could be financed. Narrow fiduciary obligations impose a restriction and only allow the financing of projects with cash flows that exceed a certain threshold. In case, for example, fiduciary obligations are set so narrowly, $b=0$, that the investor must receive her return exclusively from cash flow, the cash flow must not be less than the investor's required return $r$. On the surface, for a venture to be attractive, it must cover the investor's required return $r$ and the entrepreneur's reservation salary $x$, meaning that the sum of cash flow $f$ and expected opportunity po exceed the sum of the required return $r$ and the reservation salary $x: f+p o>r+x$. As cash flows decrease, the investor must receive a greater participation, given that he does not receive all the opportunities. The upper bound to the participation of the investor in the project is $100 \%$. Projects that produce total expected value $f+p o$ in excess of the required return on capital and the reservation salary $r+x$ will be feasible only if they can be financed with the investor receiving no more that $100 \%$ of the project. Call the total expected value of the venture $v$, where $v=f+p o$. The cash flows $f$ are a fraction $a$ of total project value, implying $f=$ $a v$, and $o=v(1-a) / p$. The share $s$ of the project that the investor requires can be rewritten as follows:

$$
\begin{aligned}
& s=\frac{r}{f+p b o} \\
& s=\frac{r}{v(a+b-a b)}
\end{aligned}
$$$$
\Leftrightarrow
$$ 
The issue, however, is not to calculate the necessary fiduciary obligation $b$ given constant total expected project value $v$ while the cash-flow ratio $a$ changes. Rather we must determine the level of fiduciary obligations that investors require as the total value changes. This requires us to determine the total expected value that is necessary to finance a project given a constant ratio $a$ of cash flow to total value as fiduciary obligations change. Solving the above for $v$, and setting $s=1$, we get:

$$
v=\frac{r}{a+b-a b}
$$

The following figure illustrates how, as cash flows become a smaller fraction of total project value, fiduciary obligations must be broad ( $b$ large) for projects to be financed.

An example will illustrate the impossibility of financing cash-poor projects if fiduciary obligations are low. Suppose that with a cash investment of $\$ 6$ and entrepreneurial effort corresponding to a reservation salary of $\$ 4$ a project can be undertaken where total expected project value $v$ is $\$ 12$. The investor requires a $10 \%$ return, dictating an expected payment of $\$ 6.60$. A certain cash flow $f$ constitutes $40 \%$ of value or $\$ 4.80$. Thus, the project will generate $\$ 7.20$ in expected opportunities (in any combination of probability and magnitude). If fiduciary obligations $b$ are interpreted so as to award the entrepreneur all opportunities to the creation of which the entrepreneur has contributed more than $10 \%$ $(b=.1)$, then the total expected value of opportunities available to the project is $\$ 0.72$. Therefore, even if the investor were given $100 \%$ of the project by receiving all the shares, the investor would not receive the required return. Despite the fact that the project apparently creates a profit of $20 \%$ on the investment, it cannot be financed.

Thus, the proportion of project value that is predictable cash flow determines whether a project will be financed under the current level of fiduciary obligations. Of course the effect will vary by the capital intensity of the project and 
the interest rate the investors require, which in turn will correspond to the project's risk. The following figure presents a set of feasibility boundaries, i.e., boundaries which, given a project's total return, indicate what level of fiduciary obligation is necessary for the project to be financed. The case of projects of moderate capital intensity and moderate interest rates ( $60 \%$ capital, $10 \%$ rate) is compared with the case of projects of high capital intensity (80\%) and high interest rates (20\%).

\section{The Feasibility of Projects under Risk-Neutral Entrepreneurs}

Moderate Capital Intensity, Moderate Interest Rates
High Capital Intensity, High Interest Rates
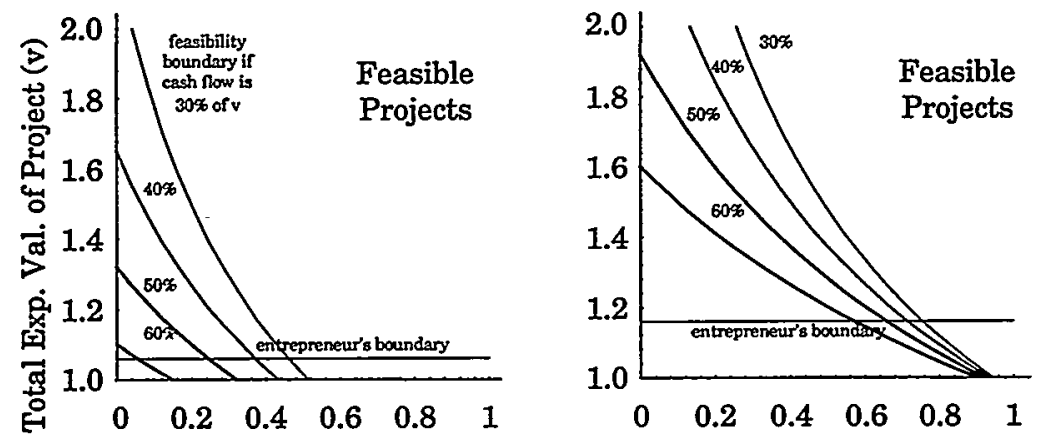

Level of Fiduciary Obligations (b)

Figure 1 provides an illustration of the limitations of financing otherwise appealing projects due to narrow fiduciary obligations. Projects require total investment of 1 , cash of .6 and managerial/entrepreneurial activity corresponding to a reservation salary of .4. Investors require $10 \%$ return, or $r=.66$. While the entrepreneur will undertake all projects with total expected value exceeding 1.06 , the investor will only invest if either fiduciary obligations are broad enough to participate in the opportunities, or if the project is rich in cash flows. The figure graphs the boundaries for financing projects given the fraction of their total expected value that is cash flow. This effect will be much more pronounced as the capital intensity of the project increases where broader fiduciary obligations will be necessary to finance more projects. 
Assuming that the entrepreneur is risk-averse, ventures must provide more than $r+x$ to entice the entrepreneur to undertake them.

The manager-entrepreneur has a utility of wealth function $U()$, and a reservation salary $x$. The entrepreneur's expected utility from engaging in the venture has three components. If, with probability $1-p$, the opportunity does not materialize, the entrepreneur will enjoy the utility of her share $(1-s)$ of the cash flow $f$. If an opportunity that is corporate materializes, with probability $p b$, the entrepreneur will enjoy the utility of her share of both cash flow and opportunity, $f+o$. Finally, if an opportunity arises which she can appropriate, with probability $p(1-b)$, she enjoys her share of the cash but all of the opportunity. Thus, the entrepreneur's expected utility from the venture $E U$ is:

$$
\begin{aligned}
& E U=(1-p) U[(1-s) f]+p b U[(1-s)(f+o)]+ \\
& p(1-b) U[(1-s) f+o]
\end{aligned}
$$

Remember that total expected value of the venture $v$ is $f$ $+p o$ and that cash flows $f=a v$, and $o=v(1-a) / p$. Making these substitutions in the above formulation of the entrepreneur's expected utility from the venture, as well as substituting the investor's share $s$ by $r /(f+p b o)$, and subtracting the entrepreneur's reservation utility $U(x)$, produces the excess utility of the project $y$. When that is negative, the entrepreneur will not engage in the project: 


$$
\begin{aligned}
& y=E U-U(x)= \\
& (1-p) U\left[\left(1-\frac{r}{f+p b o}\right) a v\right]+ \\
& p b U\left[\left(1-\frac{r}{f+p b o}\right)\left(a v+\frac{v(1-a)}{p}\right)\right]+ \\
& p(1-b) U\left[\left(1-\frac{r}{f+p b o}\right) a v+\frac{v(1-a)}{p}\right]-U(x)
\end{aligned}
$$

The three first terms correspond again to (a) no opportunity materializing in which case the entrepreneur shares the cash flow $a v$, (b) an opportunity that is corporate arising, in which case the entrepreneur shares cash and opportunity, and (c) a non-corporate opportunity occurring, in which case the entrepreneur shares the cash but appropriates the opportunity.

To illustrate the feasible ventures while varying the total value $v$ and the fiduciary obligations $b$, the following figure uses the constant relative risk aversion function $U(x)$ $=x^{1 \cdot \bullet} /(1-\bullet)$ and a moderate coefficient of risk aversion $\bullet=$ 1.5. ${ }^{18}$ Because a closed-form solution for the entrepreneur's indifference curves with $y=0$ is unattainable, we must derive numerical solutions. The venture requires a total investment that is normalized to 1 with the investor supplying capital of .6 and requiring $r=.66$ and the entrepreneur providing effort of $x=.4$. These figures correspond to a mildly capital intensive project needing $60 \%$ of the total investment in capital on which the investor requires a $10 \%$ return. The opportunity materializes with $40 \%$ probability

${ }_{18}$ See generally Kenneth J. Arrow, The Theory of Risk-Aversion, reprinted in COLLECTED PAPERS OF KENNETH J. ARROW at 147 (3d ed. 1984). 
$p=.4$. The indifference curves separate attractive projects, where $y>0$, from unattractive ones, given projects that produce their payoffs with different combinations of cash and opportunity.

This setting will be juxtaposed with one of higher capital intensity and interest rates where $80 \%$ financing is necessary and the investors require a $20 \%$ rate. Feasible projects are again to the upper right and infeasible ones to the lower left, separated by the indifference curve that is appropriate for each project's expected mix of cash flow and opportunity. For example, in a legal regime where the entrepreneur may appropriate any opportunity to which he has contributed more than $10 \%$, a project that doubles the invested resources will not be financed if cash flows are 30\% of expected value. However, the project will be financed if cash flows are $40 \%$ or more (point $A$ on the figure). As another example, consider projects that produce $20 \%$ profit and cash flows that make up 50\% of their total expected value. For such projects to be financed, fiduciary obligations must be interpreted broadly enough so as to allow the entrepreneur to appropriate only opportunities to the creation of which she has contributed by $60 \%$ or more (point $B$ on the figure). 


\section{The Feasibility of Projects without \\ Rich Cash Flows for the Risk-Averse Entrepreneur}

\section{Moderate Capital Intensity, Moderate Interest Rates

\author{
High Capital Intensity, \\ High Interest Rates
}

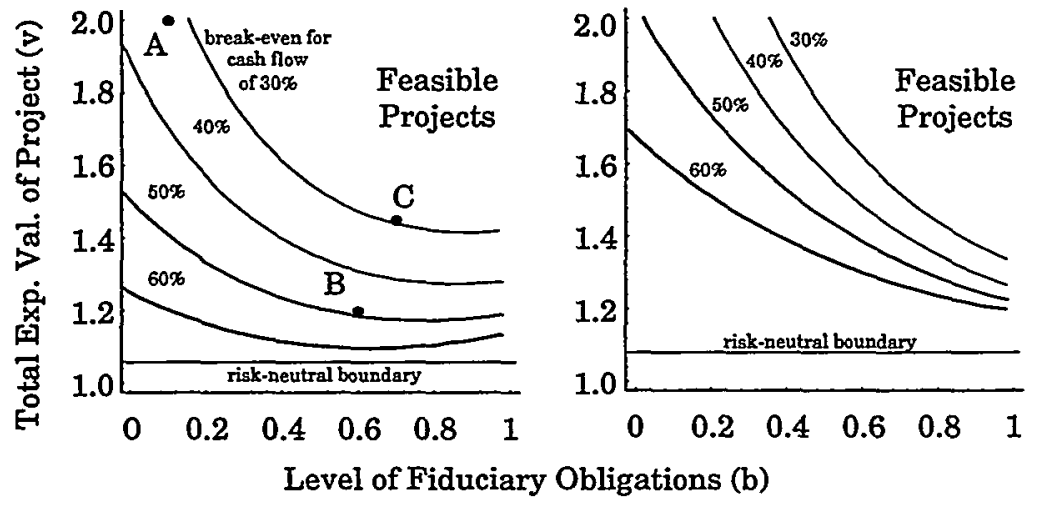

Figure 2 illustrates how fiduciary obligations determine the attractiveness of projects. The level of fiduciary obligation lies on the $\mathrm{x}$ axis, and the total expected value of the venture on the $y$ axis. The left figure corresponds to a mildly capital intensive project requiring $60 \%$ of the investment in capital on which a $10 \%$ return is necessary. The line at $v$ $=1.06$ (marked risk-neutral boundary) corresponds to the total value which would suffice to make the project attractive assuming riskneutrality. The right figure considers projects requiring $80 \%$ capital which must return 20\%. Their risk-neutral boundary is at $v=1.16$. The entrepreneur's "break-even curves" demarcate the attractive projects assuming a different proportion of the project's value comes from its cash flows (as opposed to the opportunities to which it will give rise). The more scarce the cash flows, the more expansive fiduciary obligations must be in order for the entrepreneur to consider the project attractive. Even a project which is expected to produce $45 \%$ of profit, if only $30 \%$ of its returns are in cash flows, will not be undertaken unless fiduciary obligations are defined expansively so as to give the venture all opportunities up to those in which the entrepreneur contributes more than $70 \%$ to their creation (point $\mathrm{C}$ on the left graph). The fact that for cashrich projects the optimal fiduciary obligation is fairly low also shows that a financing vehicle associated with lower or no fiduciary obligations, such as debt, should also exist. 
Of course, the level of fiduciary obligations would only be culpable for reduced investment if the individual decisions of the investor and entrepreneur differ from those of a selffinancing entrepreneur. The self-financing entrepreneur's opportunity cost of capital is equal to the investor's required return. The reservation salary remains unchanged. The self-financing entrepreneur will enjoy all the cash flow and every opportunity regardless of its distance from the project. Therefore, the expected utility has only two terms: either the opportunity does not materialize, or it does. The project will be pursued if its expected utility compensates for the opportunity cost, the foregone utility of the salary and return on capital:

$$
E U-U(r+x)=(1-p) U[a v]+p U[v]-U(r+x)
$$

It is impossible to know, however, how much less riskaverse (than an impecunious entrepreneur) the selffinancing entrepreneur would be. If he were amply wealthy, he may be risk-neutral with respect to the return on his capital for it would be part of his diversified portfolio. Otherwise, he may well avoid projects that could have been pursued under divided financing and management and optimal fiduciary obligations. Thus, broad fiduciary duties are not only necessary for divided financing and management, but more of the risky projects will be undertaken under divided financing and management than by self-financing entrepreneurs. Indeed, it would be irrationally optimistic for legal-economic systems that do not foster financing separated from entrepreneurship to expect that selffinancing entrepreneurs would undertake all the projects that would be undertaken under optimal fiduciary obligations. 